\title{
Decay of $\gamma-\mathrm{H} 2 \mathrm{AX}$ foci correlates with potentially lethal damage repair in prostate cancer cells
}

\author{
BREGJE VAN OORSCHOT ${ }^{1}$, SUZANNE E. HOVINGH ${ }^{1}$, HANS RODERMOND ${ }^{1}$, AHMED GÜÇLÜ ${ }^{1}$, \\ NIENKE LOSEKOOT ${ }^{1}$, ALBERT A. GELDOF ${ }^{2}$, GERRIT W. BARENDSEN ${ }^{1}$, \\ LUKAS J. STALPERS ${ }^{1}$ and NICOLAAS A.P. FRANKEN ${ }^{1}$ \\ ${ }^{1}$ Department of Radiation Oncology, Laboratory for Experimental Oncology and Radiobiology (LEXOR), \\ Center for Experimental Molecular Medicine, Academic Medical Center, University of Amsterdam; \\ ${ }^{2}$ Free University Hospital, Amsterdam, The Netherlands
}

Received November 13, 2012; Accepted December 30, 2012

DOI: $10.3892 /$ or.2013.2364

\begin{abstract}
To determine the relationship between ionizing radiation-induced levels of $\gamma-\mathrm{H} 2 \mathrm{AX}$ foci and cell survival in cultured prostate cancer cell lines, three prostate cancer cell lines: LNCaP (wt TP53), DU145 (mut TP53) and PC3 (TP53 null), were studied. For $\gamma$-H2AX foci induction, cells were irradiated with a single dose of $2 \mathrm{~Gy}$ and foci levels were studied at $30 \mathrm{~min}$ and $24 \mathrm{~h}$ after irradiation. Cell survival was determined by clonogenic assay, directly and $24 \mathrm{~h}$ after irradiation with doses ranging from 0 to $8 \mathrm{~Gy}$. Irradiation was performed with a Siemens Stabilipan $250 \mathrm{KeV}$ X-ray machine at a dose rate of approximately $3 \mathrm{~Gy} / \mathrm{min}$. Survival curves were analyzed using the linear-quadratic model $\mathrm{S}(\mathrm{D}) / \mathrm{S}(0)=$ $\exp -\left(\alpha \mathrm{D}+\beta \mathrm{D}^{2}\right)$. LNCaP cells clearly demonstrated potentially lethal damage repair (PLDR) which was assessed as increased survival levels after delayed plating as compared to cells plated immediately after irradiation. DU145 cells demonstrated only a slight PLDR and PC3 cells did not show PLDR at all. Levels of $\gamma-\mathrm{H} 2 \mathrm{AX}$ foci were significantly decreased in all cell lines at $24 \mathrm{~h}$ after irradiation, compared to levels after $30 \mathrm{~min}$. The LNCaP cells which demonstrated a clear PLDR also showed the largest decay in the number of $\gamma$-H2AX foci. In addition, the PC cells which did not show PLDR had the lowest decay of $\gamma-\mathrm{H} 2 \mathrm{AX}$ foci. A clear correlation was demonstrated between the degree of decay of $\gamma-\mathrm{H} 2 \mathrm{AX}$ foci and PLDR.
\end{abstract}

\section{Introduction}

DNA double-strand breaks (DSBs) are generally assumed to play a major role in radiation-induced cell death (1).

Correspondence to: Dr N.A.P. Franken, Department of Radiation Oncology, Laboratory for Experimental Oncology and Radiobiology (LEXOR), Center for Experimental Molecular Medicine, Academic Medical Centre, University of Amsterdam, P.O. Box 22700, 1100 DE Amsterdam, The Netherlands

E-mail: n.a.franken@amc.uva.nl

Key words: $\gamma-\mathrm{H} 2 \mathrm{AX}$ foci, lethal cell damage, potentially lethal damage repair, TP53, prostate cancer cell, linear-quadratic model
Phosphorylation of the histone protein $\mathrm{H} 2 \mathrm{AX}(\gamma-\mathrm{H} 2 \mathrm{AX})$ is one of the earliest markers of DNA damage after ionizing radiation. These $\gamma$-H2AX ionizing radiation-induced foci (IRIF), which appear already at $3 \mathrm{~min}$ after irradiation and increase in time reaching a maximum at 20-30 min after irradiation, have been reported to mark the locations of DNA DSBs (2-7). After the breaks are rejoined, $\gamma-\mathrm{H} 2 \mathrm{AX}$ is dephosphorylated again. The disappearance of the foci is related to repair of the DNA (8).

An important factor in responses of cells to irradiation is potentially lethal damage repair (PLDR). Repair of PLD is usually complete between 6 and $12 \mathrm{~h}$ after irradiation (9). PLDR can be studied with delayed plating experiments of plateau-phase cultures. Survival of cells plated after a delay of $24 \mathrm{~h}$ following irradiation is compared with survival of cells plated directly after irradiation (10-13). In cells demonstrating PLDR, cell survival is enhanced if the cells are allowed to remain undisturbed for some time after irradiation before they are assayed for colony formation $(10,11)$. Several studies have demonstrated that PLDR can be influenced by the status of the tumor protein 53 (TP53) (14-18). However, some studies have suggested that PLDR does not depend on functional TP53 (19-21).

Survival curves are commonly described and analyzed using the linear-quadratic (LQ) model: $S(D) / S(0)=\exp$ $-\left(\alpha D+\beta D^{2}\right)(22-24)$. Studies investigating the repair of potentially lethal damage are critical as factors influencing PLDR may alter tumor radiocurability. The advantage of using the LQ model is that changes in PLDR can be determined quantitatively by analyses of the linear parameter $\alpha$, describing the low dose range of the survival curve, separately from the parameter $\beta$ dominating the high dose range $(10,25-27)$. Analysis of survival curves from numerous studies has shown that PLDR is most clearly demonstrated by changes of the linear parameter $\alpha(24,28-30)$.

The relationship between radiation sensitivity and the induction of $\gamma$-H2AX IRIF is not always clear. Foci of $\gamma-\mathrm{H} 2 \mathrm{AX}$ are also induced by factors other than ionizing radiation, such as during the process of replication. Not all cell lines have similar numbers of $\gamma-\mathrm{H} 2 \mathrm{AX}$ foci after equal radiation doses. Several studies showed that the induction of $\gamma-\mathrm{H} 2 \mathrm{AX}$ 
foci is not directly correlated with the cellular survival after radiation $(4,31)$. However, it has been demonstrated that there is a correlation between the number of residual DNA DSBs at $10 \mathrm{~h}$ after irradiation and cell survival $(32,33)$. Previous studies suggested that the induction of $\gamma$-H2AX after single and fractionated irradiation appears to be a useful marker of cellular radiosensitivity $(8,34)$.

The aim of the present study was to establish whether PLDR is correlated with repair of DNA DSB. As the status of TP53 is important for PLDR (16), the level of PLDR was determined in three prostate cell lines with different TP53 status. Then, the induction of $\gamma$-H2AX foci after a 2 Gy dose was determined directly and $24 \mathrm{~h}$ after radiation. The data indicate correlations between TP53 status and PLDR, and decay of $\gamma$-H2AX foci and the level of PLDR.

\section{Materials and methods}

Cell cultures. Human prostate cancer cell lines with different status of TP53 were used: LNCaP, wt TP53; PC3, TP53 null; and DU145, mut TP53, as previously described (35-37). All three cell lines were cultured in RPMI-1640 medium (Gibco, Invitrogen) supplemented with $10 \%$ fetal calf serum, $100 \mathrm{U} / \mathrm{ml}$ penicillin/streptomycin and $1 \mathrm{mM}$ glutamine in a humidified atmosphere of $5 \% \mathrm{CO}_{2} / 95 \%$ air. The doubling time of all three cell lines was $24 \mathrm{~h}$.

Western blotting. Western blotting of TP53 induction at $4 \mathrm{~h}$ after $4 \mathrm{~Gy}$ is shown in Fig. 1. In LNCaP cells, TP53 was induced at $4 \mathrm{~h}$ after $4 \mathrm{~Gy}$; in DU145 cells, the mutated TP53 protein was present before and after irradiation; and in PC3 cells, no TP53 was detected. Erk-2 protein was used for loading control.

Radiation treatment. Confluent cultures of cells growing in monolayers were irradiated at $37^{\circ} \mathrm{C}$ in a waterbath and $5 \%$ $\mathrm{CO}_{2} / 95 \%$ air was supplied during irradiation. Irradiation was performed with a Stabilipan $250 \mathrm{KeV}$ X-ray machine (Siemens, Germany). For determination of $\gamma-\mathrm{H} 2 \mathrm{AX}$ foci, a radiation dose of 2 Gy was applied and for the survival experiments cells were exposed to single doses of $0,2,4,6$ and $8 \mathrm{~Gy}$. The distance between the focus and the culture dish was $9 \mathrm{~cm}$. A $0.5-\mathrm{mm} \mathrm{Cu}$ filter was used and the dose rate was $\sim 3 \mathrm{~Gy} / \mathrm{m}$.

Clonogenic survival. Directly and $24 \mathrm{~h}$ after irradiation, cells were trypsinized and replated for clonogenic survival assay in appropriate cell numbers in 6-well macroplates $(38,39)$. Subsequently, cells were incubated for 10 days. Surviving colonies were fixated and stained with glutaraldehyde-crystal violet solution and counted. Survival curves were analyzed using SPSS statistical software (Chicago, IL, USA) by means of fit of data by weighted linear regression, according to the linearquadratic formula: $S(D) / S(0)=\exp -\left(\alpha D+\beta D^{2}\right)(10,27,40,41)$. In the formula, the $S(D)$ is the survival at dose $D$ and $S(0)$ is the survival at dose 0 . As a measure of PLDR, the ratio PLD- $\alpha$ is calculated as the ratio of the value of linear parameter $\alpha$ of cells immediately plated (ip) after irradiation and cells delayed plated (dp) $24 \mathrm{~h}$ after irradiation.

Immunohistochemistry for $\gamma-H 2 A X$. We counted the number of $\gamma$-H2AX foci in cells that were grown on cover slides $(42,43)$. The

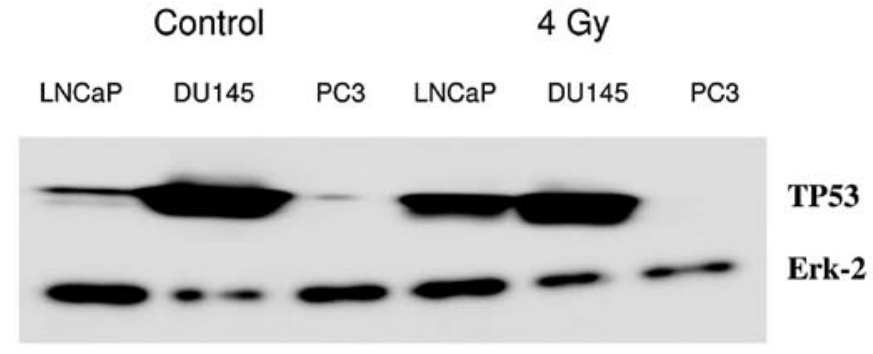

Figure 1. Western blot analysis of TP53 status in LNCap, DU145 and PC3 prostate cancer cells. Induction of TP53 was measured at $4 \mathrm{~h}$ after $4 \mathrm{~Gy}$. Clear induction of TP53 in LNCaP (wt TP53), no induction TP53 in DU145 (mut TP53) and absence of TP53 in PC3 (TP53 null) cells.

cover slides $(21 \times 26 \mathrm{~mm})$ were sterilized with alcohol and were placed in $60-\mathrm{mm}$ cell culture dishes. The cells were reseeded at a density of $2.5 \times 10^{5}$ cells on cell culture dishes containing sterile cover slides and were grown until a confluent layer was obtained. The cells were then irradiated. The number of $\gamma$-H2AX foci was determined $30 \mathrm{~min}$ and $24 \mathrm{~h}$ after irradiation.

Following irradiation, cells were washed with phosphatebuffered saline (PBS) and fixed in PBS containing 2\% paraformaldehyde for $15 \mathrm{~min}$. After three further washes with PBS, cells were treated with PBS containing 0.1\% Triton X-100 and $1 \%$ FCS (TNBS) for 30 min to permeabilize the cells.

A primary mouse monoclonal anti- $\gamma-\mathrm{H} 2 \mathrm{AX}$ antibody (Millipore) was diluted 1:100 in TNBS. Fixed, permeabilized cells on the cover slides were incubated with $50 \mu$ l primary antibody under a parafilm strip for $90 \mathrm{~min}$ at room temperature. Cells were then washed with PBS for $\sim 5 \mathrm{~min}$ and the parafilm strip was removed. Subsequently, cells were washed 2 times with TNBS.

Cells on cover slides were incubated with $50 \mu 1$ secondary antibody anti-Mouse Cy3 (Jackson) (1:100 in TNBS) under a parafilm strip for $30 \mathrm{~min}$ at room temperature. Cells were then washed 2-3 times with TNBS for $\sim 5$ min and the parafilm strip was removed. Nuclei were stained with DAPI $(2.5 \mu \mathrm{g} / \mathrm{ml})$ for $5 \mathrm{~min}$ and embedded in Vectashield. Then, cover slides were sealed to microscope slides. Rubber cement was used to seal the whole construct.

$\gamma-H 2 A X$ foci scoring. Digital image analysis was performed to determine the number of $\gamma-\mathrm{H} 2 \mathrm{AX}$ IRIF. Fluorescent photomicrographs of $\gamma-\mathrm{H} 2 \mathrm{AX}$ foci were obtained using Image Pro Plus software. Stack images of cells were obtained using a Leica DM RA HC Upright Microscope equipped with a CCD camera. Stack images of 50 cells/sample were captured using Image Pro Plus software. One stack image consisted of 23 slices with a 300-nm interval between the slices along the $\mathrm{Z}$-axis. Images were then processed and the number of foci in cells was scored using custom-made software (42-45).

All experiments were carried out in triplicates, independently from each other. Numbers of foci in unirradiated control cells were subtracted from numbers in irradiated samples. S-phase cells were excluded using an EdU (5-ethynyl-2'-deoxyuridine) staining (Invitrogen, Eugene, OR, USA) to mark these cells. The ratio of the number of $\gamma-\mathrm{H} 2 \mathrm{AX}$ foci at $30 \mathrm{~min}$ and $24 \mathrm{~h}$ after irradiation was calculated as a measure of foci decay resulting from repair of DNA DSBs. 

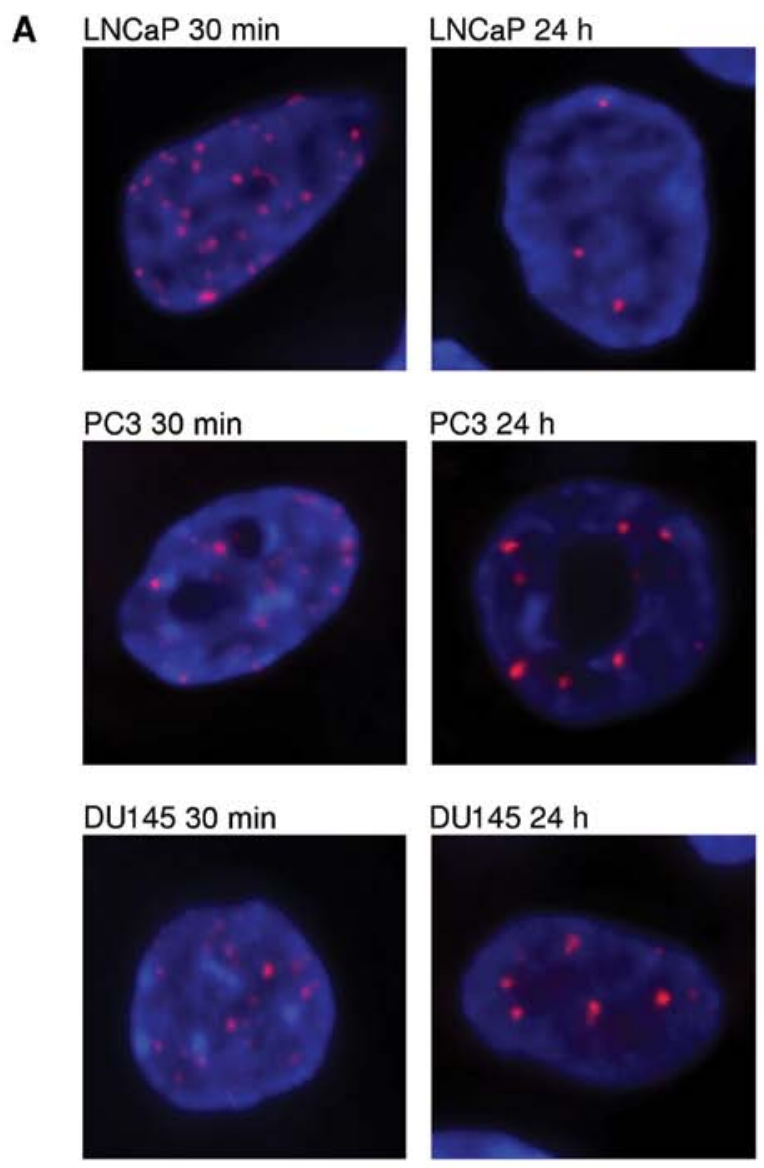

B

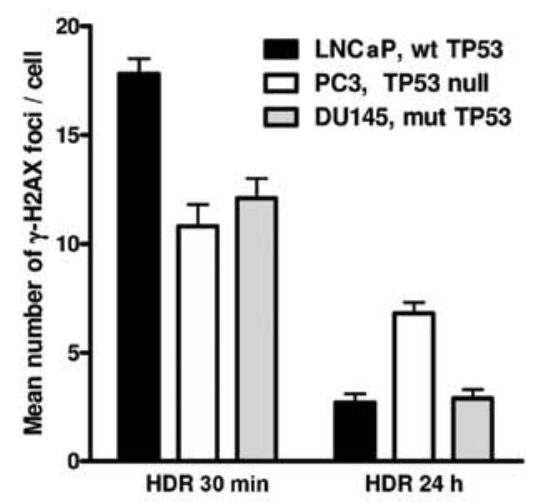

Figure 2. (A) Representative nuclei of LNCAP, DU145 and PC3 cells with $\gamma-\mathrm{H} 2 \mathrm{AX}$ foci at $30 \mathrm{~min}$ and $24 \mathrm{~h}$ after $2 \mathrm{~Gy}$. (B) Quantification of the number of $\gamma$-H2AX foci. At least 150 cells are counted in 3 different experiments; error indicates standard error of the mean (SEM) $\mathrm{N}=3$.

\section{Results}

To assess TP53 status of the used cell lines, western blot analysis was performed of TP53 induction after 4 Gy radiation dose (Fig. 1). In LNCaP cells, wt TP53 induction was visible; in the DU145 cells, mutant TP53 was present; and in the PC3 cells, no TP53 was observed.

Fig. 2 shows the radiation-induced number of $\gamma-\mathrm{H} 2 \mathrm{AX}$ foci in the different prostate cancer cells. At $30 \mathrm{~min}$ after irradiation, LNCaP cells had the highest number and PC3 cells had the lowest number of $\gamma$-H2AX foci. On the contrary,
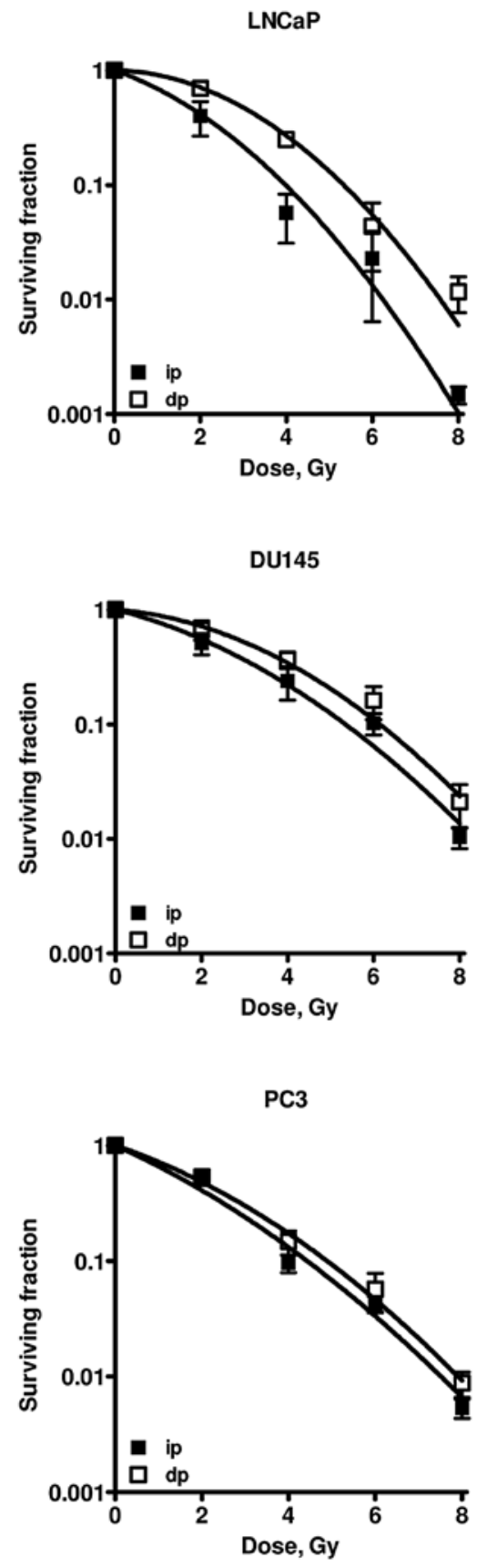

Figure 3. Survival curves of the different prostate cancer cell lines immediately plated (ip) after irradiation and delayed plated (dp) $24 \mathrm{~h}$ after irradiation. LNCaP show clear PLDR, DU145 show only slight PLDR and PC3 do not show PLDR. PLDR is the increase in survival after dp as compared to ip. Error bars indicate standard error of the mean (SEM) $\mathrm{N}=3$.

$24 \mathrm{~h}$ post-treatment PC3 cells had the highest number and LNCaP cells had the lowest number of foci. The DU145 cells had intermediate numbers of foci for both post-irradiation conditions. Initial number of foci at $30 \mathrm{~min}$ after irradiation ranged between 10 and 18 foci/cell. At $24 \mathrm{~h}$ after treatment, the numbers ranged between 2.7 and 7 foci/cell. The decline in foci number was the highest for LNCaP cells and the lowest for PC3 cells.

Survival curves of the different cell lines are presented in Fig. 3. LNCaP and DU145 cells clearly showed increased survival after dp as compared to ip cells after irradiation. 
Table I. LQ parameters $\alpha$ and $\beta$, PLD- $\alpha$, ratio of foci decay and the TP 53 status of the different prostate cancer cell lines.

\begin{tabular}{|c|c|c|c|c|c|}
\hline LQ parameter cell line & $\alpha, \mathrm{Gy}^{-1}$ & $\beta, \mathrm{Gy}^{-2}$ & PLDR- $\alpha$ & Ratio foci decay & TP53 status \\
\hline \multicolumn{6}{|l|}{ LNCaP } \\
\hline ip & $0.31 \pm 0.09$ & $0.08 \pm 0.03$ & $10.3 \pm 3.9$ & $6.9 \pm 0.3$ & $\mathrm{TP}^{+} 3^{+}$ \\
\hline $\mathrm{dp}$ & $0.03 \pm 0.01$ & $0.08 \pm 0.02$ & & & \\
\hline \multicolumn{6}{|l|}{ DU145 } \\
\hline ip & $0.22 \pm 0.06$ & $0.04 \pm 0.01$ & $3.1 \pm 1.6$ & $4.2 \pm 0.7$ & TP53 mutated \\
\hline $\mathrm{dp}$ & $0.07 \pm 0.03$ & $0.05 \pm 0.01$ & & & \\
\hline \multicolumn{6}{|l|}{ PC3 } \\
\hline ip & $0.39 \pm 0.04$ & $0.03 \pm 0.01$ & $1.3 \pm 0.22$ & $1.6 \pm 0.2$ & TP53 null \\
\hline $\mathrm{dp}$ & $0.30 \pm 0.04$ & $0.04 \pm 0.01$ & & & \\
\hline
\end{tabular}

LQ, linear-quadratic; PLDR, potentially lethal damage repair; ip, cells immediately plated after irradiation; dp, cells delayed plated $24 \mathrm{~h}$ after irradiation. Error indicates standard error of the mean (SEM) N=3.

Table II. Surviving fraction and the number of radiation-induced $\gamma$-H2AX foci after 2 Gy.

\begin{tabular}{|c|c|c|c|c|c|c|}
\hline \multirow[b]{2}{*}{2 Gy } & \multicolumn{2}{|c|}{ LNCaP } & \multicolumn{2}{|c|}{ DU145 } & \multicolumn{2}{|c|}{ PC3 } \\
\hline & Surviving fraction & No. of foci & Surviving fraction & No. of foci & Surviving fraction & No. of foci \\
\hline ip & $0.39 \pm 0.10$ & $17.8 \pm 0.7$ & $0.55 \pm 0.08$ & $12.1 \pm 0.9$ & $0.41 \pm 0.05$ & $10.8 \pm 1.0$ \\
\hline $\mathrm{dp}$ & $0.70 \pm 0.15$ & $2.7 \pm 0.4$ & $0.71 \pm 0.10$ & $2.9 \pm 0.4$ & $0.46 \pm 0.05$ & $6.8 \pm 0.5$ \\
\hline
\end{tabular}

ip, cells immediately plated after irradiation and foci after $30 \mathrm{~min}$; dp, cells delayed plated and foci at $24 \mathrm{~h}$ after irradiation. Error indicates standard error of the mean (SEM) $\mathrm{N}=3$.

Survival curves of PC3 cells plated immediately and $24 \mathrm{~h}$ after irradiation do not show any difference. Values of the linear and quadratic parameters, $\alpha$ and $\beta$, the PLD- $\alpha$ ratio $\left(=\alpha_{\mathrm{ip}} / \alpha_{\mathrm{dp}}\right)$ as a measure of PLDR, the ratio of the number of $\gamma$-H2AX foci at $30 \mathrm{~min}$ and $24 \mathrm{~h}$ after irradiation, and the TP53 status of the different cell lines are presented in Table I. The decay of foci correlates well with PLDR. In Table II, the surviving fractions and the number of foci after 2 Gy are given for immediately and delayed plated cells. It can be observed that in almost all cases, high survival levels correlated with low residual foci numbers and, vice versa, low survival levels correlated with high residual numbers of foci.

\section{Discussion}

The three prostate tumor cell lines examined in this study differ in their TP53 status. The TP53 status was confirmed with western blotting. In LNCaP cells, TP53 was induced $4 \mathrm{~h}$ after 4 Gy irradiation; in DU145 cells, the mutated TP53 protein was present before and after irradiation; in PC3 cells, TP53 was not detected at all. Earlier studies reported that an intact TP53 status is required for repair of potentially lethal damage (14-17). Therefore, the level of PLDR was investigated in the three cells lines. The LNCaP cells with wt TP53 protein clearly demonstrated PLDR. As expected, in the DU145 cell line harbouring mutated TP53 PLDR was reduced and in the PC3 cells (TP53 null) PLDR was not seen at all.
Furthermore, the present data demonstrates that the decay of $\gamma$-H2AX foci after 2 Gy radiation dose correlates with PLDR. Phosphorylation of H2AX occurs rapidly after induction of DNA DSB. The $\gamma-\mathrm{H} 2 \mathrm{AX}$ foci have been suggested to be a valid measure for radiosensitivity and the disappearance of the foci might be related to the repair of DNA damage following radiation treatment (8). It has already been shown by MacPhail et al (46) that the decay of $\gamma-\mathrm{H} 2 \mathrm{AX}$ foci is associated with cell survival and repair of DSB. Yoshikawa et al (31) suggested that there was no close correlation between residual foci and radiosensitivity in some tumor cell lines. However, Yoshikawa et al (31) only studied survival of cells plated immediately after irradiation. In our study, we irradiated cells and plated them both directly and $24 \mathrm{~h}$ after irradiation in order to study PLDR. The cell line with the highest PLDR was also found to have the largest decay in number of foci, resembling a more proficient repair of DNA DSB. This is also corroborated by our observation that higher surviving fractions after 2 Gy correlated with a lower number of residual $\gamma$-H2AX foci in the prostate cell lines (Table II).

The linear-quadratic model is based on well-accepted biophysical concepts, involving the assumption that lethal damage can be induced by single-particle tracks and by interaction of damage from multiple particles.

In a review of published data on the dependence of different types of lethal damage on the linear energy transfer of ionizing particles, Barendsen $(23,25,26)$ derived evidence that sublethal lesions and potentially lethal lesions show similar RBE-LET 
(relative biological effect-linear energy transfer) relationships as DNA DSBs, with only a relatively low RBE at the optimal LET (27). This is evidently different from the high RBE values commonly derived for unrepairable lethal lesions and chromosome aberrations. The hypothesis was proposed that sublethal lesions and potentially lethal lesions are both DNA-DSBs. The present results on the decay of $\gamma$-H2AX foci, which mark DNA DSBs, and the correlation with PLD repair are consistent with this hypothesis. Potentially lethal lesions contribute only a part to the linear parameter $\alpha$ in the LQ model and are similarly repairable as sublethal damage. In earlier studies, we demonstrated a correlation between survival, chromosomal aberrations and PLDR, which was shown by a decrease in the value of $\alpha$ with higher survival and lower number of chromosomal aberrations $(12,13)$. Herein, we further demonstrated that there is an association between PLDR $\alpha$ and a decrease of DNA DSB, which strengthens the biological basis of the LQ model. However, our study remains to be confirmed in an isogenic system with cells only different in TP53 status.

\section{Acknowledgements}

The authors thank the Maurits and Anna de Kock and the Nijbakker Morra foundations for sponsoring the fluorescence microscopes with software to study the $\gamma$-H2AX foci. The Dutch Cancer Foundation (nos. UVA 2008-4019 and UVA 2012-5540) and the Stichting Vanderes are acknowledged for financing personnel support.

\section{References}

1. Frankenberg-Schwager M: Induction, repair and biological relevance of radiation-induced DNA lesions in eukaryotic cells. Radiat Environ Biophys 29: 273-292, 1990.

2. Aten JA, Stap J, Krawczyk PM, van Oven CH, Hoebe RA, Essers J and Kanaar R: Dynamics of DNA double-strand breaks revealed by clustering of damaged chromosome domains. Science 303: 92-95, 2004.

3. Lau P, Baumstark-Khan C, Hellweg CE and Reitz G: $\mathrm{X}$-irradiation-induced cell cycle delay and DNA double-strand breaks in the murine osteoblastic cell line OCT-1. Radiat Environ Biophys 49: 271-280, 2010.

4. Beels L, Werbrouck J and Thierens H: Dose response and repair kinetics of gamma-H2AX foci induced by in vitro irradiation of whole blood and T-lymphocytes with X- and gamma-radiation. Int J Radiat Biol 86: 760-768, 2010.

5. Vandersickel V, Depuydt J, Van Bockstaele B, Perletti G, Philippe J, Thierens $\mathrm{H}$ and Vral A: Early increase of radiationinduced $\gamma \mathrm{H} 2 \mathrm{AX}$ foci in a human Ku70/80 knockdown cell line characterized by an enhanced radiosensitivity. J Radiat Res 51: 633-641, 2010.

6. Mosconi M, Giesen U, Langner F, Mielke C, Dalla Rosa I and Dirks WG: 53BP1 and MDC1 foci formation in HT-1080 cells for low- and high-LET microbeam irradiations. Radiat Environ Biophys 50: 345-352, 2011.

7. Zlobinskaya O, Dollinger G, Michalski D, Hable V, Greubel C, Du G, Multhoff G, Röper B, Molls M and Schmid TE: Induction and repair of DNA double-strand breaks assessed by gammaH2AX foci after irradiation with pulsed or continuous proton beams. Radiat Environ Biophys 51: 23-32, 2012.

8. Olive PL and Banáth JP: Phosphorylation of histone H2AX as a measure of radiosensitivity. Int J Radiat Oncol Biol Phys 58 331-335, 2004.

9. Hall EJ and Garcia AJ: Radiobiology for the Radiologist. 6th edition. Lippincott Williams \& Wilkins, Philadelphia, PA, 2006.

10. Franken NA, van Bree C, Kipp JB and Barendsen GW: Modification of potentially lethal damage in irradiated Chinese hamster V79 cells after incorporation of halogenated pyrimidines. Int J Radiat Biol 72: 101-109, 1997.
11. Franken N, van Bree C, Streefkerk J, Kuper I, Rodermond H, Kipp J and Barendsen G: Radiosensitization by iodo-deoxyuridine in cultured SW-1573 human lung tumor cells. Oncol Rep 4: 1073-1076, 1997.

12. Franken NA, Ruurs P, Ludwików G, van Bree C, Kipp JB Darroudi F and Barendsen GW: Correlation between cell reproductive death and chromosome aberrations assessed by FISH for low and high doses of radiation and sensitization by iodo-deoxyuridine in human SW-1573 cells. Int J Radiat Biol 75: 293-299, 1999.

13. Franken NA, van Bree C, Veltmaat MA, Ludwików G, Kipp JB and Barendsen GW: Increased chromosome exchange frequencies in iodo-doxyuridine-sensitized human SW-1573 cells after $\gamma$-irradiation. Oncol Rep 6: 59-63, 1999.

14. Schwartz JL, Jordan R, Kaufmann WK, Rasey J, Russell KJ and Weichselbaum RR: Evidence for the expression of radiationinduced potentially lethal damage being a p53-dependent process. Int J Radiat Biol 76: 1037-1043, 2000.

15. Schwartz JL, Rasey J, Wiens L, Jordan R and Russell KJ: Functional inactivation of p53 by HPV-E6 transformation is associated with a reduced expression of radiation-induced potentially lethal damage. Int J Radiat Biol 75: 285-291, 1999.

16. Franken NA, van Bree $\mathrm{C}$, ten Cate $\mathrm{R}$, van Oven $\mathrm{CH}$ and Haveman J: Importance of TP53 and RB in the repair of potentially lethal damage and induction of color junctions after exposure to ionizing radiation. Radiat Res 158: 707-714, 2002.

17. Franken NA, van Bree C and Haveman J: Differential response to radiation of TP53-inactivated cells by overexpression of dominantnegative mutant TP53 or HPVE6. Radiat Res 161: 504-510, 2004.

18. Devlin HL, Mack PC, Burich RA, Gumerlock PH, Kung HJ, Mudryj M and deVere White RW: Impairment of the DNA repair and growth arrest pathways by $\mathrm{p} 53 \mathrm{R} 2$ silencing enhances DNA damage-induced apoptosis in a p53-dependent manner in prostate cancer cells. Mol Cancer Res 6: 808-818, 2008.

19. Danielsen T, Smith-Sørensen B, Grønlund HA, Hvidsten M, Børresen-Dale AL and Rofstad EK: No association between radiosensitivity and TP53 status, G1 arrest or protein levels of $\mathrm{p} 53$, myc, ras or raf in human melanoma lines. Int J Radiat Biol 75: 1149-1160, 1999.

20. van Bree C, Savonije JH, Franken NA, Haveman J and Bakker PJ: The effect of p53-function on the sensitivity to paclitaxel with or without hyperthermia in human colorectal carcinoma cells. Int $\mathbf{J}$ Oncol 16: 739-744, 2000.

21. van Bree C, Franken NA, Rodermond HM, Stalpers LJ and Haveman J: Repair of potentially lethal damage does not depend on functional TP53 in human glioblastoma cells. Radiat Res 161: 511-516, 2004.

22. Barendsen GW: Dose fractionation, dose rate and iso-effect relationships for normal tissue responses (review). Int J Radiat Oncol Biol Phys 8: 1981-1997, 1982.

23. Barendsen GW: RBE-LET relationships for different types of lethal radiation damage in mammalian cells: comparison with DNA dsb and an interpretation of differences in radiosensitivity. Int J Radiat Biol 66: 433-436, 1994.

24. Barendsen GW: Parameters of linear-quadratic radiation doseeffect relationships: dependence on LET and mechanisms of reproductive cell death. Int J Radiat Biol 71: 649-655, 1997.

25. Barendsen GW: Sublethal damage and DNA double strand breaks have similar RBE-LET relationships: evidence and implications. Int J Radiat Biol 63: 325-330, 1993.

26. Barendsen GW: The relationships between RBE and LET for different types of lethal damage in mammalian cells: biophysical and molecular mechanisms (review). Radiat Res 139: 257-270, 1994.

27. Barendsen GW, van Bree C and Franken NA: Importance of cell proliferative state and potentially lethal damage repair on radiation effectiveness: Implications for combined tumor treatments (Review). Int J Oncol 19: 247-256, 2001.

28. Franken NA, Hovingh S, Rodermond H, Stalpers L, Barendsen GW and Crezee J: Radiosensitization with chemotherapeutic agents and hyperthermia: Effects on the linear-quadratic parameters of radiation cell survival curves. J Cancer Sci Ther S5: 002 doi: 10.4172/1948-5956, 2011.

29. Franken NA, Hovingh S, Oei A, Cobussen P, Bergs JW, van Bree C, Rodermond HM, Stalpers LJ, Kok P, Barendsen GW and Crezee J: Radiosensitization with hyperthermia and chemotherapeutic agents: Effects on linear-quadratic parameters of radiation cell survival curves (Review). In: Ionizing Radiation/ Book 1. Mitsuru N. Intech Publisher, 2012.

30. van Bree C, Franken NA, Bakker PJ, Klomp-Tukker LJ, Barendsen GW and Kipp JB: Hyperthermia and incorporation of halogenated pyrimidines: radiosensitization in cultured rodent and human tumor cells. Int J Radiat Oncol Biol Phys 39: 489-496, 1997. 
31. YoshikawaT,KashinoG,Ono Kand Watanabe M: Phosphorylated $\mathrm{H} 2 \mathrm{AX}$ foci in tumor cells have no correlation with their radiation sensitivities. J Radiat Res 50: 151-160, 2009.

32. Dikomey E and Brammer I: Relationship between cellular radiosensitivity and non-repaired double-strand breaks studied for different growth states, dose rates and plating conditions in a normal human fibroblast line. Int J Radiat Biol 76: 773-781, 2000.

33. Banáth JP, Klokov D, MacPhail SH, Banuelos CA and Olive PL: Residual gammaH2AX foci as an indication of lethal DNA lesions. BMC Cancer 10: 4, 2010.

34. Klokov D, MacPhail SM, Banáth JP, Byrne JP and Olive PL: Phosphorylated histone H2AX in relation to cell survival in tumor cells and xenografts exposed to single and fractionated doses of X-rays. Radiother Oncol 80: 223-229, 2006.

35. DeWeese TL, Shipman JM, Dillehay LE and Nelson WG: Sensitivity of human prostatic carcinoma cell lines to low dose rate radiation exposure. J Urol 159: 591-598, 1998.

36. Geldof AA and Slotman BJ: Radiosensitizing effect of cisplatin in prostate cancer cell lines. Cancer Lett 101: 233-239, 1996.

37. Geldof AA, Plaizier MA, Duivenvoorden I, Ringelberg M, Versteegh RT, Newling DW and Teule GJ: Cell cycle perturbations and radiosensitization effects in a human prostate cancer cell line. J Cancer Res Clin Oncol 129: 175-182, 2003.

38. Franken NAP, Rodermond HM, Stap J, Haveman J and van Bree C: Clonogenic assay of cells in vitro. Nat Protoc 1 : 2315-2319, 2006.

39. Bergs JW, Franken NA, ten Cate R, van Bree C and Haveman J: Effects of cisplatin and gamma-irradiation on cell survival, the induction of chromosomal aberrations and apoptosis in SW-1573 cells. Mutat Res 594: 148-154, 2006.

40. Franken NA, van Bree C, Veltmaat MA, Rodermond HM, Haveman J and Barendsen GW: Radiosensitization by bromodeoxyuridine and hyperthermia: analysis of linear and quadratic parameters of radiation survival curves of two human tumor cell lines. J Radiat Res 42: 179-190, 2001
41. Franken NA, ten Cate R, van Bree $\mathrm{C}$ and Haveman J: Induction of the early response protein EGR-1 in human tumour cells after ionizing radiation is correlated with a reduction of repair of lethal lesions and an increase of repair of sublethal lesions. Int J Oncol 24: 1027-1031, 2004.

42. Franken NA, ten Cate R, Krawczyk PM, Stap J, Haveman J, Aten $J$ and Barendsen GW: Comparison of RBE values of high-LET $\alpha$-particles for the induction of DNA-DSBs, chromosome aberrations and cell reproductive death. Radiat Oncol 6: 64, 2011.

43. Franken NA, Hovingh SE, ten Cate R, Krawczyk PM, Stap J, Hoebe R, Aten J and Barendsen GW: Relative biological effectiveness of high linear energy transfer $\alpha$-particles for the induction of DNA-double-strand breaks, chromosome aberrations and reproductive cell death in SW-1573 lung tumour cells. Oncol Rep 27: 769-774, 2012.

44. Ludwików G, Xiao Y, Hoebe RA, Franken NA, Darroudi F, Stap J, Van Oven CH, Van Noorden CJ and Aten J: Induction of chromosome aberrations in unirradiated chromatin after partial irradiation of a cell nucleus. Int $\mathbf{J}$ Radiat Biol 78: 239-247, 2002.

45. Bergs JW,Krawczyk PM, Borovski T, ten Cate R, Rodermond HM, Stap J, Medema JP, Haveman J, Essers J, van Bree C, Stalpers LJ, Kanaar R, Aten J and Franken NA: Inhibition of homologous recombination by hyperthermia shunts early double strand break repair to non-homologous end-joining. DNA Repair (Amst) 12: 38-45, 2013.

46. MacPhail SH, Banáth JP, Yu TY, Chu EH, Lambur H and Olive PL: Expression of phosphorylated histone H2AX in cultured cell lines following exposure to X-rays. Int J Radiat Biol 79: 351-358, 2003. 